\title{
Acetoclastic Methanosaeta are dominant methanogens in organic-rich Antarctic marine sediments
}

\author{
Stephanie A Carr ${ }^{1}$, Florence Schubotz ${ }^{2}$, Robert B Dunbar ${ }^{3}$, Christopher T Mills ${ }^{4}$, \\ Robert Dias $^{4}$, Roger E Summons ${ }^{5}$ and Kevin W Mandernack ${ }^{6}$ \\ ${ }^{1}$ Bigelow Laboratory for Ocean Sciences, East Boothbay, ME, USA ${ }^{2}$ MARUM Center for Marine Environmental \\ Sciences, University of Bremen, Bremen, Germany; ${ }^{3}$ Department of Environmental Earth Systems Science, \\ Stanford University, Stanford, CA, USA; ${ }^{4} U S$ Geological Survey, Denver Federal Center, Denver, CO, USA; \\ ${ }^{5}$ Department of Earth, Atmospheric and Planetary Sciences, Massachusetts Institute of Technology, \\ Cambridge, MA, USA and ${ }^{6}$ Department of Earth Sciences, Indiana University - Purdue University \\ Indianapolis, Indianapolis, IN, USA
}

\begin{abstract}
Despite accounting for the majority of sedimentary methane, the physiology and relative abundance of subsurface methanogens remain poorly understood. We combined intact polar lipid and metagenome techniques to better constrain the presence and functions of methanogens within the highly reducing, organic-rich sediments of Antarctica's Adélie Basin. The assembly of metagenomic sequence data identified phylogenic and functional marker genes of methanogens and generated the first Methanosaeta sp. genome from a deep subsurface sedimentary environment. Based on structural and isotopic measurements, glycerol dialkyl glycerol tetraethers with diglycosyl phosphatidylglycerol head groups were classified as biomarkers for active methanogens. The stable carbon isotope $\left(\delta^{13} \mathrm{C}\right)$ values of these biomarkers and the Methanosaeta partial genome suggest that these organisms are acetoclastic methanogens and represent a relatively small $(0.2 \%)$ but active population. Metagenomic and lipid analyses suggest that Thaumarchaeota and heterotrophic bacteria co-exist with Methanosaeta and together contribute to increasing concentrations and $\delta^{13} \mathrm{C}$ values of dissolved inorganic carbon with depth. This study presents the first functional insights of deep subsurface Methanosaeta organisms and highlights their role in methane production and overall carbon cycling within sedimentary environments.
\end{abstract}

The ISME Journal (2018) 12, 330-342; doi:10.1038/ismej.2017.150; published online 17 October 2017

\section{Introduction}

Marine sediment constitutes Earth's largest reservoir of methane $\left(\mathrm{CH}_{4}\right)$ (Valentine, 2011), including continental shelf environments, which produce 0.7$14 \mathrm{Tg} \mathrm{CH}_{4}$ year $^{-1}$ (Valentine, 2002; Ferry and Lesser, 2008). Even though $\mathrm{CH}_{4}$ oxidizers consume most of this greenhouse gas (Reeburgh, 2007), it is important to understand all major subsurface sources. Sedimentary methanogens include representatives of the Methanosarcinales, Methanomicrobales, Methanococcales, Methanopyrales, Methanobacteriales and Methanomassiliicoccales orders (Sowers and Kastead 1984; Sowers and Ferry, 2003; Ferry and Kastead, 2007; Lang et al., 2015; Katayama et al., 2016). Collectively, these organisms compose a curiously

Correspondence: KW Mandernack, Department of Earth Sciences, Indiana University-Purdue University Indianapolis, Indianapolis, 723 West Michigan Street, Indianapolis, IN 46202, USA.

E-mail: kevinman@iupui.edu

Received 17 January 2017; revised 16 June 2017; accepted 24 June 2017; published online 17 October 2017 small proportion of sequenced communities observed in $\mathrm{CH}_{4}$-rich, subsurface environments (Valentine, 2011). Less than $4 \%$ of archaeal $16 \mathrm{~S}$ rRNA gene clone libraries generated from the $\mathrm{CH}_{4}$-bearing sediment of the Peru and Cascadia margins represented methanogens (Parkes et al., 2005; Inagaki et al., 2006). Functional gene surveys of these margins also identified fewer copies of the methyl coenzyme $\mathrm{M}$ reductase (mcrA) than predicted based on $\mathrm{CH}_{4}$ concentrations (Colwell et al., 2008; Biddle et al., 2008). This scarcity of detectable methanogens has raised the following hypotheses: (i) that primer-based sequencing may be biased against methanogens or (ii) that methanogens may be highly active relative to the total microbial population (Parkes et al., 2005; Inagaki, et al., 2006). In any case, limited observations of methanogens in subsurface environments restrict our understanding of $\mathrm{CH}_{4}$ production in these settings.

The Adélie Basin, Antarctica is a long, narrow shelf with high surface water diatom primary productivity (Leventer et al., 2006), which results in high sedimentation rates and anoxic conditions. 
The sediments are characterized by negligible sulfate and increasing $\mathrm{CH}_{4}$ concentrations with depth, indicating active methanogenesis (Expedition Scientists 318 et al., 2011b). Despite geochemical evidence for $\mathrm{CH}_{4}$ production, a sequencing survey of the 16S rRNA gene identified $<0.1 \%$ of the sequenced community as methanogens (Carr et al., 2015). To further investigate the scant methanogenic community in this basin, this study circumvented primer-based methods and generated three metagenomes from sample depths 14, 25 and $100 \mathrm{~m}$ below seafloor (mbsf). The identification of methanogen genomic markers at depth $14 \mathrm{~m}$ prompted further characterization of the communities within the top $20 \mathrm{~m}$ of sediment. This study utilized structural and isotope analyses of intact polar lipids (IPLs) and bacterial polar lipid fatty acids as an independent and complimentary method for identifying and quantifying viable microorganisms in situ (Zink et al., 2003; Lipp et al., 2008). Using IPLs with glycerol dialkyl glycerol tetraether (GDGT) core lipids as a proxy to estimate viable archaeal populations has been recently challenged because the observed decay of glycosidic ether lipids is one to two orders of magnitude slower than bacterial phospholipids (Xie et al., 2013), suggesting that glycosidic ether lipids may be remnants of fossil planktonic archaea (Schouten et al., 2010). Therefore, this study focused on phosphatidic IPLs as diagnostic markers for viable archaea.

The $\delta^{13} \mathrm{C}$ values of diagnostic lipids can also help elucidate carbon metabolisms (Pancost and Sinninghe Damsté, 2003; Biddle et al., 2006; Schubotz et al., 2011; Mills et al., 2013; Carr et al., 2013). Methanogens are known to convert carbon dioxide $\left(\mathrm{CO}_{2}\right)$, acetate and/or small methylated compounds to $\mathrm{CH}_{4}$. $\mathrm{CO}_{2}$ reduction is thought to be the principle pathway in marine sediments (Whiticar et al., 1986); however, consumption of acetate can be significant in sulfate-depleted environments, while methanogens using non-competitive methylated substrates can exist wherever those compounds are abundant (Ferdelman et al., 1997; Fitzsimons et al., 1997). The family Methanosarcinaceae is considered to be the most versatile group of methanogens: some species can metabolize all three types of substrates (Sowers and Ferry, 2003; Ferry and Kastead, 2007). A study of Methanosarcina barkeri suggested that stable carbon isotope fractionation between lipids and substrate $\left(\Delta_{\text {substrate-lipid }}\right)$ was greatest when cultures were grown on methylated substrates $\left(\Delta_{\text {substrate- }}\right.$ lipid $=33-46 \%$ ) (Londry et al., 2008). Less fractionation was observed during growth on $\mathrm{CO}_{2}\left(\Delta_{\text {substrate- }}\right.$ lipid $=11-20 \%$ o $)$ and acetate $\left(\Delta_{\text {substrate-lipid }}=2-6 \%\right.$ o $)$. Notably, variations in growth conditions also affected fractionation, suggesting that $\delta^{13} \mathrm{C}_{\text {lipids }}$ values alone are not sufficient for predicting the metabolic pathway. Here we compare $\delta^{13} \mathrm{C}_{\mathrm{IPLs}}$ values to dissolved inorganic carbon (DIC) and total organic carbon (TOC) to estimate $\Delta^{13} \mathrm{C}_{\text {lipid-substrate }}$ values. $\Delta^{13} \mathrm{C}_{\text {lipid-substrate }}$ values were combined with the metagenomic evidence to predict the dominant methanogenic pathway occurring within the sediments. Additionally, we measured $\delta^{13} \mathrm{C}$ values of polar lipid fatty acids to better characterize bacterial carbon cycling and identify potential synergistic interactions between bacteria and methanogens (for example, cycling of fermentation products such as small organic substrates or hydrogen, Nobu et al., 2015).

\section{Methods}

Site description and sampling strategy

Sediments were collected from IODP Hole U1357C (Expedition 318 Scientists, 2011a), directly off the Wilkes Land Margin (66 $24.8^{\prime} \mathrm{S}, 140^{\circ} 25.5^{\prime} \mathrm{E}$, water depth $1017 \mathrm{~m}$, sedimentation rate $\sim 2 \mathrm{~cm} \mathrm{year}^{-1}$ ). A complete description of our sampling strategy was reported by Expedition 318 Scientists (2011b) and Carr et al. (2015). Briefly, alternate 10-cm-length whole round samples were taken for lipid and interstitial water geochemistry analyses within the top $20 \mathrm{~m}$. Additional $5 \mathrm{~cm}^{3}$ syringe samples were collected for DNA analyses reaching a depth of 103.65 mbsf. Shipboard analyses included DIC, $\mathrm{CH}_{4}$ and sulfate concentrations (Expedition 318 Scientists, 2011a). DIC increases from 40 to $80 \mathrm{~mm}$ at $18.27 \mathrm{mbsf}$ (Figure 1). $\mathrm{CH}_{4}$ concentrations suggest a maximum of $12.8 \mathrm{~mm}$ at 21.61 mbsf; however, gas expansion likely caused gas loss during core recovery. Thus it is possible that $\mathrm{CH}_{4}$ concentrations were saturated throughout the shallow core sections. Samples for $\delta^{13} \mathrm{C}_{\mathrm{CH} 4}$ analysis were not taken; however, ethane concentrations were negligible $(<1 \mathrm{ppmv})$, indicating that the bulk of the $\mathrm{CH}_{4}$ was biogenic. Sulfate is depleted to below detection within $2 \mathrm{~m}$, higher concentrations of sulfate observed at the top of each 9-m-core section suggest seawater contamination. These potentially contaminated samples were excluded from shore-based analyses. Sulfide gas was not measured, although a sulfidic odor was apparent. Total organic nitrogen and TOC concentrations for the top 18 of core were reported previously (Carr et al., 2016). TOC concentrations decreased with depth from $\sim 2.0 \mathrm{wt} \%$ to $1.4 \mathrm{wt} \%$ at $18.37 \mathrm{mbsf}$. Total organic nitrogen concentrations were relatively constant and averaged $0.30 \mathrm{wt} \%$. Consequently $\mathrm{C} / \mathrm{N}$ decreased with depth, averaging 5.6 and suggesting a large marine contribution to the TOC pool.

To confirm the validity of unique methanogen lipid biomarkers, IPLs from the Adélie Basin were compared with those of a $\mathrm{CH}_{4}$-free control site located on the continental rise-IODP Hole U1359B $\left(64^{\circ} 54.2^{\prime} \mathrm{S}, 143^{\circ} 57.7^{\prime} \mathrm{E}\right.$, water depth $3021 \mathrm{~m}$, sedimentation rate $\sim 20 \mathrm{~m} \mathrm{My}^{-1}$ ). Ten-cm whole rounds samples were collected for IPL analysis.

Stable carbon isotope analyses of carbon substrates $\delta^{13} \mathrm{C}$ analyses of DIC were conducted at the Stable Isotope Biogeochemistry Laboratory at Stanford University. $\mathrm{CO}_{2}$ was evolved from DIC using 


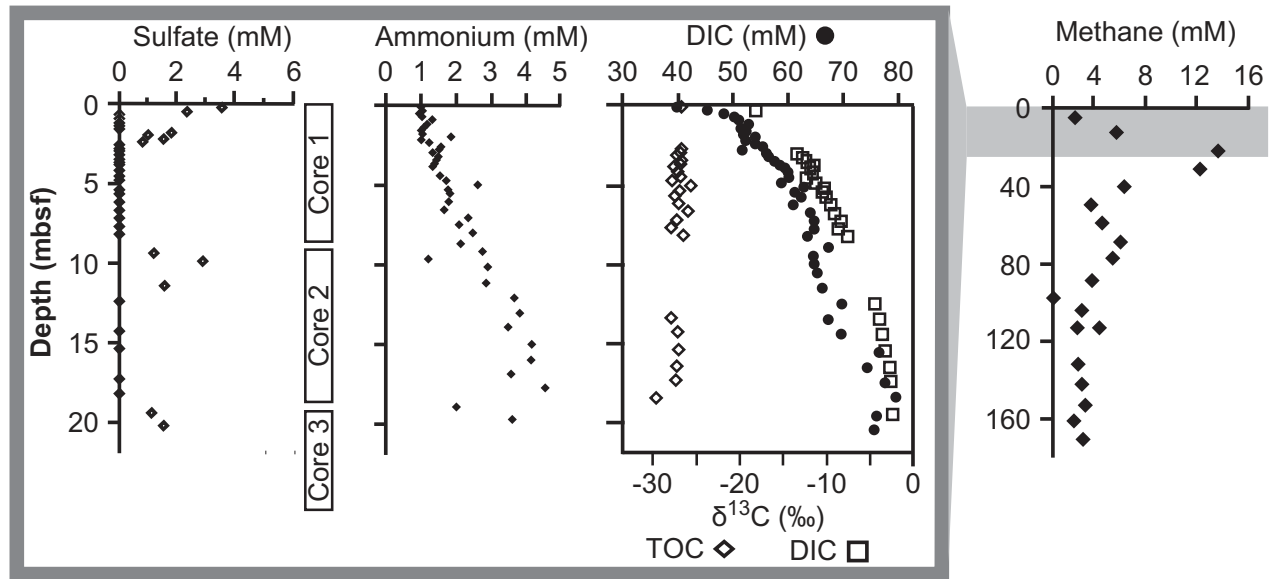

Figure 1 Depth profiles for concentrations of dissolved inorganic compounds, carbon isotopic compositions of DIC and TOC (0-20 mbsf, this study) and dissolved $\mathrm{CH}_{4}$ concentrations (0-171 mbsf) in sediment pore waters at IODP Site U1357 (Expedition 318 Scientists, $2011 \mathrm{~b}$, figure modified with permission).

cryogenic vacuum separation techniques (Gruber et al., 1999). The $\delta^{13} \mathrm{C}_{\text {DIC }}$ values were measured on a Finnigan MAT 252 isotope ratio mass spectrometer (IRMS). Sediment for TOC measurements were lyophilized, homogenized, loaded into silver capsules and acidified with a 6\% sulfurous acid solution. Isotopic measurements were made with a Carlo Erba NA 1500 elemental analyzer/Conflo II system (CE Elantech, Inc., Lakewood, NJ, USA) coupled to a Finnigan DeltaPlus IRMS (Thermo Fisher Scientific, Waltham, MA, USA). The $\delta^{13} \mathrm{C}$ values of DIC and TOC were reported in the standard delta notation relative to Vienna Pee Dee Belemnite (VPDB) with $0.05 \%$ precision.

\section{Metagenome analyses}

Genomic DNA was extracted from Hole U1357C sample depths 14, 25 and $100.5 \mathrm{mbsf}$ (97.4 and 103 mbsf pooled) using a phenol chloroform protocol modified from Zhou et al. (1996) as described in Carr et al. (2015). DNA was concentrated using a PowerClean Pro DNA Clean-Up Kit (Mo Bio Laboratories, Inc., Solana Beach, CA, USA). Metagenomic sequencing was performed at the WM Keck sequencing facility at the Marine Biological Laboratory. Library preparation, sequencing, quality control and assembly are described within the Supplementary Information. Briefly, paired-end sequencing of DNA was performed on an Illumina NextSeq 500 (Illumina, Inc., San Diego, CA, USA). Raw reads are available in NCBI's Short Read Archive, accession numbers SAX2769041-SRX2769043. Adapter removal, quality assessment and filtering was performed using the BBmap software version 35.14 (Bushnell, 2015). Community coverage was estimated using Nonpareil (Rodriguez-R and Konstantinidis, 2014). Sequence reads from all depths were co-assembled using MEGAHIT (Li et al., 2015) and binned using CONCOCT (Alneberg et al., 2014) via the platform anvi'o (Eren et al., 2015). This assembly is available on the Joint Genome Institute's Integrated Microbial Genome Expert Review platform (IMG/M, ID 3300008470, Markowitz et al., 2014). Binning generated 70 bins, one of which was classified as a methanogen (genus Methanosaeta). The original paired-end reads of this Methanosaeta bin and any contig that contained coding regions for methanogenic genes were reassembled (SPAdes genome assembler v3.7.1, Bankevich et al., 2012), binned (CONCOCT via anvi'o) and manually inspected twofold. Completeness and contamination of the final Methanosaeta genome from a metagenome (GFM) was assessed against an established list of Euryarchaeota single copy genes (UID49) using CheckM (Parks et al., 2015). The Methanosaeta GFM was annotated using the IMG automated pipeline (Taxon ID 2687453729, Markowitz et al., 2014). Annotations were verified against those obtained using myrast (Aziz et al., 2008). Genomes average nucleotide identity (ANI) comparisons were calculated using the IMG/ER 'pairwise ANI tool' (Supplementary Information) and orthologous gene clusters (OGCs) were compared using OrthoVenn, using the default settings (Wang et al., 2015).

Putative 16S rRNA genes were assembled from individual sample depths using Meta-RNA (Huang et al., 2009) and EMIRGE (Miller et al., 2011), aligned and classified against the SILVA non-redundant database (v123, Quast et al., 2013) and quantified using kallisto 0.42.4 (Bray et al., 2016; Supplementary Information).

\section{Lipid extraction, analysis and quantification}

Total lipids extracts were generated from 10 10-cm whole round samples and bacterial-derived polar lipid fatty acids were converted to fatty acid methyl esters (FAMEs) and were identified and quantified according to Carr et al. (2016). Total lipids extract aliquots were also analyzed both in the Summons laboratory at MIT and the Hinrichs laboratory at the MARUM. Identification and quantification of IPLs 
and core GDGTs was achieved on a Agilent 1200 series HPLC system coupled to an Agilent 6520 accurate-mass quadrupole time-of-flight mass spectrometer (Summons laboratory, Agilent, Santa Clara, CA, USA) and Dionex Ultimate 3000 UHPLC (Thermo Fisher Scientific, Waltham, MA, USA) coupled to a Bruker maXis ultra-high-resolution orthogonal acceleration quadrupole time-of-flight tandem MS2 instrument (Hinrichs laboratory, Bruker Daltonics Inc., Billerica, MA, USA) following previously described protocols (Becker et al., 2013; Wörmer et al., 2013; Zhu et al., 2013; Supplementary Information). Archaeal IPLs were identified by exact masses and diagnostic fragmentation patterns (Yoshinaga et al., 2011) using automated datadependent fragmentation of base peak ions. Quantification of IPLs occurred using C46 GDGT as an internal standard (Huguet et al., 2006), taking response factors of available archaeal IPLs into account (see Supplementary Information for details of quantification and error estimations) with a detection limit of ca. $100 \mathrm{pg}$ on column. The Methane Index (MI) and Branched and Isoprenoid Tetraether (BIT) Index were calculated after Zhang et al. (2011) and Hopmans et al. (2004), respectively.

Preparative HPLC-MS was performed on five samples (sample depth: 2.55, 7.17, 14.25, 17.25, and $18.87 \mathrm{mbsf}$ ) to separate total lipids extracts into fractions that contain different archaeal IPLs for determining head group-specific stable carbon isotopic compositions. Separation of IPL-GDGTs was achieved by reverse phase chromatography using a Zorbax Eclipse XDB C18 column $(5 \mu \mathrm{m}, 10 \times 250 \mathrm{~mm}$, Agilent Technologies, Santa Clara, CA, USA) on an Agilent 1200 series high-performance liquid chromatography (HPLC) system equipped with an Agilent 1200 series fraction collector (Supplementary Information).

Preparation of lipid derivatives for GC-isotope ratio mass spectrometric analysis

The $\delta^{13} \mathrm{C}$ of the FAMEs was determined by GCcombustion-IRMS at the US Geological Survey (Denver, CO, USA). FAMEs were separated on an Agilent 6890 GC equipped with an Agilent J\&W DBPetro column $(100 \mathrm{~m}$ length $\times 0.25 \mathrm{~mm}$ id $\times 0.50 \mu \mathrm{m}$ film thickness). FAMEs were combusted on-line and a VG Optima IRMS measured the resulting $\mathrm{CO}_{2}$. The $\delta^{13} \mathrm{C}$ values were corrected for the added carbon during methylation and values are reported in $\delta$ notation, expressed against VPDB.

To obtain $\delta^{13} \mathrm{C}$ values of head group-separated archaeal IPLs, individual IPL-GDGT fractions were subjected to ether cleavage after Jahn et al., (2004) yielding biphytanes (Supplementary Information). The $\delta^{13} \mathrm{C}$ values of biphytanes were determined in the Summons and the Hinrichs laboratory using a ThermoFinningan GC coupled to a ThermoFinnigan Deltaplus XP isotope ratio MS via a GC-combustion interface (Thermo Fisher Scientific, Waltham, MA,
USA) as described previously (Schubotz et al., 2011, 2013). Samples were subjected to duplicate or triplicate measurements if enough material was present. Values are reported in the $\delta$ notation relative to the VPDB standard.

\section{Results and discussion}

\section{Genomic support for Methanogens}

Metagenomic overview. The metagenomic sequence data set from 14 mbsf (45 363249 paired-end reads) was twice as large as the other two data sets (23 662967 and 23748505 paired-end reads for 25 and $100 \mathrm{mbsf}$, respectively). Quality control steps reduced data sets to 45353241,23657716 and 23743085 paired-end reads, respectively. Community coverage was calculated using Nonpareil, a program that evaluates the redundancy of overlapping unassembled reads. The coverage at each sample depth was estimated to be $>97 \%$ using the default settings, suggesting a sequencing depth $>400 \times$ (Supplementary Figure S1). The final coassembly was $1.2 \mathrm{Gbp}$ on 1368184 contigs with an N50 of $860 \mathrm{bp}$.

A total of 362 putative full-length 16S rRNA gene sequences were assembled using Emirge from identified 16S rRNA gene fragments. These sequences resemble those of previous pyrosequenced libraries (Figure 2, Carr et al., 2015), demonstrating congruity between the two different approaches. Candidate phylum Atribacteria was the most abundant phylum in all libraries and increased with abundance with depth. A single-cell amplified genome, classified as Atribacteria, was recently isolated from this site (Carr et al., 2015) and suggested that these Atribacteria produce fermentation products such as acetate, ethanol and $\mathrm{CO}_{2}$, which could support a methanogenic community (Carr et al., 2015). Other relatively abundant phyla shared between the data sets included Bacteroidetes, Gammaproteobacteria, Planctomycetes and Alphaproteobacteria. Euryarchaeota represented only $1-2 \%$ relative abundance in both the pyrosequenced and metagenomic data sets. Only one known methanogen, classified within the genus Methanosaeta, was identified in the $14 \mathrm{mbsf}$, representing 5 and $0.2 \%$ of the archaeal and total $16 \mathrm{~S}$ rRNA sequences assembled with Emirge, respectively.

General description of Methanosaeta GFM. From our metagenomic co-assembly, we reconstructed the first known methanogen GFM from a Methanosaeta sp. originating from deep-sea marine sediments. Methanosaeta species are speculated to be the predominant $\mathrm{CH}_{4}$ producers on Earth (Smith and Ingram-smith, 2007), although relatively few have been isolated from the environment (Patel, 1984; Ma et al., 2006; Barber et al., 2011). To our knowledge, Methanosaeta pelagica, sampled from estuarine tidal

\author{
.
}




\begin{tabular}{|c|c|c|c|c|c|c|}
\hline \multirow{2}{*}{\multicolumn{3}{|c|}{$\begin{array}{c}\text { Pyrosequenced Libraries } \\
14.25 \text { mbsf } 25.24 \text { mbsf } 97.41 \text { mbsf }\end{array}$}} & \multicolumn{4}{|c|}{ Metagenome Libraries } \\
\hline & & & $14.25 \mathrm{mbs}$ & $5.24 \mathrm{mb}$ & $7.41 \mathrm{mbsf}$ & \\
\hline $30 \%$ & $29 \%$ & $49 \%$ & $24 \%$ & $32 \%$ & $33 \%$ & \multirow{21}{*}{$\begin{array}{l}\text { Atribacteria } \\
\text { Bacteroidetes } \\
\text { Gammaproteobacteria } \\
\text { Planctomycetes } \\
\text { Alphaproteobacteria } \\
\text { Firmicutes } \\
\text { other Bacteria } \\
\text { Actinobacteria } \\
\text { Deltaproteobacteria } \\
\text { Spirochaetes } \\
\text { Chloroflexi } \\
\text { Aminicenantes } \\
\text { Euryarchaeota } \\
\text { Other Archaea } \\
\text { Acidobacteria } \\
\text { Candidate division WS1 } \\
\text { Cyanobacteria } \\
\text { Verrucomicrobia } \\
\text { Acetothermia } \\
\text { Epsilonproteobacteria } \\
\text { Thaumarchaeota }\end{array}$} \\
\hline $13 \%$ & $12 \%$ & $2 \%$ & $15 \%$ & $4 \%$ & $3 \%$ & \\
\hline $10 \%$ & $13 \%$ & $9 \%$ & $10 \%$ & $6 \%$ & $1 \%$ & \\
\hline $8 \%$ & $7 \%$ & $7 \%$ & $3 \%$ & $4 \%$ & $3 \%$ & \\
\hline $7 \%$ & $6 \%$ & $3 \%$ & $9 \%$ & $9 \%$ & $6 \%$ & \\
\hline $5 \%$ & $7 \%$ & $3 \%$ & $2 \%$ & $2 \%$ & $0 \%$ & \\
\hline $4 \%$ & $4 \%$ & $4 \%$ & $7 \%$ & $16 \%$ & $4 \%$ & \\
\hline $4 \%$ & $4 \%$ & $3 \%$ & $4 \%$ & $7 \%$ & $10 \%$ & \\
\hline $4 \%$ & $4 \%$ & $1 \%$ & $2 \%$ & $1 \%$ & $1 \%$ & \\
\hline $3 \%$ & $2 \%$ & $1 \%$ & $1 \%$ & $0 \%$ & $0 \%$ & \\
\hline $3 \%$ & $3 \%$ & $3 \%$ & $6 \%$ & $6 \%$ & $7 \%$ & \\
\hline $3 \%$ & $3 \%$ & $5 \%$ & $3 \%$ & $1 \%$ & $2 \%$ & \\
\hline $1 \%$ & $2 \%$ & $2 \%$ & $1 \%$ & $2 \%$ & $2 \%$ & \\
\hline $1 \%$ & $0 \%$ & $1 \%$ & $1 \%$ & $0 \%$ & $1 \%$ & \\
\hline $1 \%$ & $1 \%$ & $1 \%$ & $0 \%$ & $1 \%$ & $10 \%$ & \\
\hline $1 \%$ & $2 \%$ & $6 \%$ & $0 \%$ & $0 \%$ & $0 \%$ & \\
\hline $0 \%$ & $1 \%$ & $0 \%$ & $0 \%$ & $0 \%$ & $2 \%$ & \\
\hline $0 \%$ & $0 \%$ & $0 \%$ & $3 \%$ & $2 \%$ & $0 \%$ & \\
\hline $0 \%$ & $0 \%$ & $0 \%$ & $1 \%$ & $5 \%$ & $3 \%$ & \\
\hline $0 \%$ & $0 \%$ & $0 \%$ & $4 \%$ & $0 \%$ & $0 \%$ & \\
\hline $0 \%$ & $0 \%$ & $0 \%$ & $3 \%$ & $3 \%$ & $10 \%$ & \\
\hline
\end{tabular}

Figure 2 Relative abundances of putative full-length 16S rRNA genes identified in metagenomic libraries compared with those identified from previous pyrosequenced libraries (Carr et al., 2015).

Table 1 Genome characteristics of Methanosaeta genomes

\begin{tabular}{|c|c|c|c|c|c|c|}
\hline Name & Environment & Size & $G C \%$ & $16 S$ rRNA similarity & mcrA similarity & $A N I$ \\
\hline This study & Deep-sea sediment & $1.4 \mathrm{MB}$ & $54 \%$ & - & - & \\
\hline M. pelagica ${ }^{\mathrm{I}}$ & Tidal flats & NA & NA & $95 \%$ & $100 \%$ & NA \\
\hline M. harundinacea ${ }^{\mathrm{II}}$ & Anaerobic digester & $2.6 \mathrm{MB}$ & 60.6 & $96 \%$ & $85 \%$ & 73.6 \\
\hline M. thermophila $\mathrm{PT}^{\mathrm{III}}$ & Anaerobic digester & $1.9 \mathrm{MB}$ & 53.6 & $92 \%$ & $81 \%$ & 70.4 \\
\hline M. concilii ${ }^{\text {IV }}$ & Anaerobic digester & $3.0 \mathrm{MB}$ & 51.0 & $92 \%$ & $78 \%$ & 70.1 \\
\hline
\end{tabular}

Abbreviations: ANI, average nucleotide identity; GC, guanine-cytosine; NA, not applicable. Accession numbers: (I) AB679167, (II) CP003117, (III) CP000477, (IV) CP002565.

flats of Tokyo Bay is the only marine isolate (Mori et al., 2012). Its genome is not sequenced. This Methanosaeta GFM has an assembly size of $1.3 \mathrm{Mbp}$ and is estimated to be $64 \%$ complete, with minimal contamination (1.65\%, Parks et al., 2015). In all, 85\% of the GFM was assembled from the 14 mbsf sample ( $25 \mathrm{mbsf}=15 \%, 97 \mathrm{mbsf}<0.1 \%$ ). One thousand six hundred and fifty-four predicted coding regions were identified and 1098 were annotated. The Methanosaeta GFM contained a 16S rRNA gene sequence that was most similar to uncultured clones collected from marine sediments and mud volcanoes (Supplementary Figure S2). In comparison to cultured species, the GFM 16S rRNA gene sequence clustered most closely with $M$. pelagica $(95 \%$ sequence pairwise similarity, Table 1). The Methanosaeta GFM also contained an morA gene. The mcrA gene was identical to that of $M$. pelagica but only $78-85 \%$ similar to those from other genomes (Table 1). Genomic similarity was measured according to ANI values and by comparing OGCs for the available genomes (Table 1). Of the 1177 OGCs identified within the GFM, all but 3 were identified within other Methanosaeta species, and 851 (72\%) were shared by all genomes, suggesting high functional similarity (Supplementary Figure S3). The three OGC clusters could not be annotated. The GFM was most similar to Methanosaeta harundinacea, sharing 1068 OGCs and an ANI of 73.55 (Table 1; Supplementary Table S2; Supplementary Figure S3).

Methanogenic potential of Methanosaeta GFM. The Methanosaeta GFM contained many of the proteins for acetoclastic methanogenesis via the Wood-Ljungdahl pathway (Figure 3, Supplementary Table S3). Using this pathway, acetate is activated to acetyl-CoA by acetyl-CoA synthetase (acs). Acetyl-CoA is then cleaved to produce $\mathrm{CO}_{2}$ and a methyl group, which is transferred to tetrahydromethanopterin and then to 2mercaptoethanesulfonate by the carbon monoxide dehydrogenase (cdh)/acetyl-CoA decarbonylase complex and tetrahydromethanopterin S-methyltransferase 


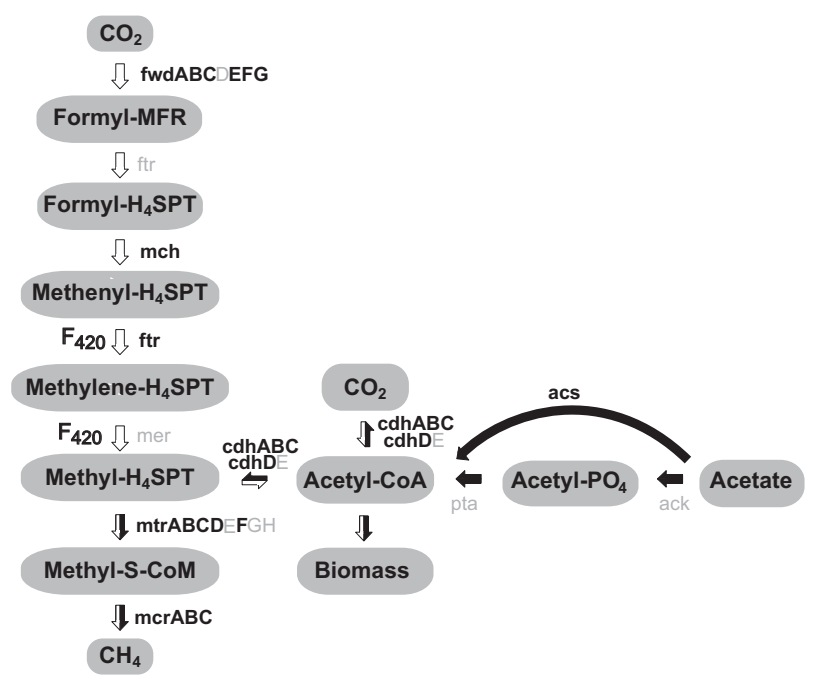

Figure 3 The enzymatic pathways of autotrophic (white arrows) and acetoclastic (black arrows) methanogenesis. Carbon substrates, intermediates and products appear in gray ovals. Enzymes present within this Methanosaeta GFM are in bold; missing enzymes or subunits appear gray. Enzymes that are absent from the Methanosaeta GFM are outlined. Enzymes: fwd: formylmethanofuran dehydrogenase; ftr: formylmethanofuran:H4SPT formyltransferase; mch: methenyl-H4SPT cyclohydrolase; mtd: F420dependent methylene H4SPT dehydrogenase; mer: F420dependent methylene-H4SPT reductase; mtr: methyl-H4SPT: coenzyme M methyltransferase; mcr: methyl-coenzymeMreductase; ack: acetate kinase; pta: phosphotransacetylase. acs: acetylCoA synthetase; cdh: carbon monoxide dehydrogenase. Carbon compounds: $\mathrm{CO}_{2}$ : carbon dioxide; formyl-MF: formyl-methanofuran; formyl-H4SPT: formyl-tetrahydrosarcinapterin; methenylH4SPT: methenyl-tetrahydrosarcinapterin; methylene-H4SPT: methylene-tetrahydrosarcinapterin; methyl-H4SPT: methylenetetrahydrosarcinapterin; methylene-S-CoM: 2-(Methylthio)ethanesulfonate. Acetyl-CoA: acetyl-Coenzyme A; Acetyl-PO acetylphosphate.

(mtr), respectively. The Methanosaeta GFM lacks subunits mtrEGH; however, considering the incompleteness of the genome bin, it is possible that all subunits are present within the organism. During the final step of methanogenesis, the original methyl group is reduced to $\mathrm{CH}_{4}$ by the three-subunit mcr, all of which were present in the GFM.

Laboratory experiments have demonstrated that $M$. harundinacea is capable of utilizing $\mathrm{CO}_{2}$ as a substrate for one-third of its $\mathrm{CH}_{4}$ production (Rotaur et al., 2014). Indeed, Methanosaeta concilii, $M$. harundinacea and M. pelagica genomes contain most of the gene-encoded proteins required for $\mathrm{CO}_{2}$ reduction. However, the lack of an energyconserving hydrogenase, and thus reducing electrons, was hard to reconcile. The experiments with $M$. harundinacea demonstrated that electrons can be acquired from syntrophic partners via electrically conductive pili (Rotaur et al., 2014). This GFM also contains genes for $\mathrm{CO}_{2}$ reduction (Figure 3). However, given that organisms with known electrically conductive pili such as Geobacter were not dominant in these sediments $(<0.5 \%$ of the pyrosequenced libraries, Carr et al., 2015), it is more likely this GFM is living syntrophically with acetogenic bacteria. To test this hypothesis, the coassembled metagenome was screened for formyltetrahydrofolate synthetase, a conserved enzyme in heterotrophic and autotrophic acetogens (Lovell et al., 1990). One hundred and thirteen formyltetrahydrofolate synthetase genes were identified (Supplementary Table S4) and classified primarily as Anaerolinea (Chloroflexi) and Atribacteria, which represented $6 \%$ and $24 \%$ of the $16 \mathrm{~S}$ rRNA gene sequences assembled from 14 mbsf using Emirge, respectively. Both lineages are believed to be heterotrophic and have been hypothesized to fuel methanogenic communities with their fermentation products (Dodsworth et al., 2013; Gies et al., 2014; Carr et al., 2015; Liang et al., 2015). For example, in North Sea sediments, a significant and positive covariance between Atribacteria and Methanosaeta organisms suggested that the groups were metabolically interactive (Nobu et al., 2015). Similarly, Anaerolineaceae and Methanosaeta organisms were found to be co-abundant in alkane degradation, $\mathrm{CH}_{4}$ producing enrichments (Liang et al., 2015). Together these observations suggest that Methanosaeta is benefiting from the fermentation products of Anaerolinea and Atribacteria and living acetoclastically in this basin.

Characterization of archaeal communities based on IPL structures

More than $90 \%$ of the recovered archaeal lipids contained saccharide (glycosidic) head groups, primarily monohexose (1G) or dihexose (2G) (Supplementary Table S4; Figures 4 and 5). Both 1G- and 2G-GDGTs were also present as their hydroxylated derivatives, 1G-OH-GDGT and 2GOH-GDGT and minor amounts of unsaturated 2GGDGTs (2G-unsat-GDGT) were detected at deeper depths. Phospho-GDGTs (2G-PG-GDGT, PH-GDGT and HPH-GDGT) comprised $0.8-5 \%$ of total archaeal lipids. 1G- and 2G-Archaeol were present at all depths (2-6\%). 1G- and 2G-Archaeols and G-GDGTs, as well as their hydroxylated counterparts, are commonly recovered from deep-sea sediments (Lipp and Hinrichs, 2009; Liu et al., 2012) and have been linked to viable benthic archaea (Lipp et al., 2008). However, 1G-GDGT has also been suggested to represent a planktonic source (Schouten et al., 2010; Xie et al., 2012), because it is abundant in planktonic archaea (Schouten et al., 2008; Elling et al., 2015) and is a potential degradation product of 2G-GDGT and HPH-GDGT (Lengger et al., 2012). Considering the amount of planktonic-derived sedimentation, high sedimentation rate and a relatively low input of terrestrial material (low BIT index, Table 2) at Hole U1357C, we exclude 1G-GDGT as a marker for viable archaea.

Phosphatidic GDGTs are more suitable biomarkers for the indigenous archaeal community as they are proposed to degrade faster than their glycosidic counterparts (Schouten et al., 2010; Lengger et al., 


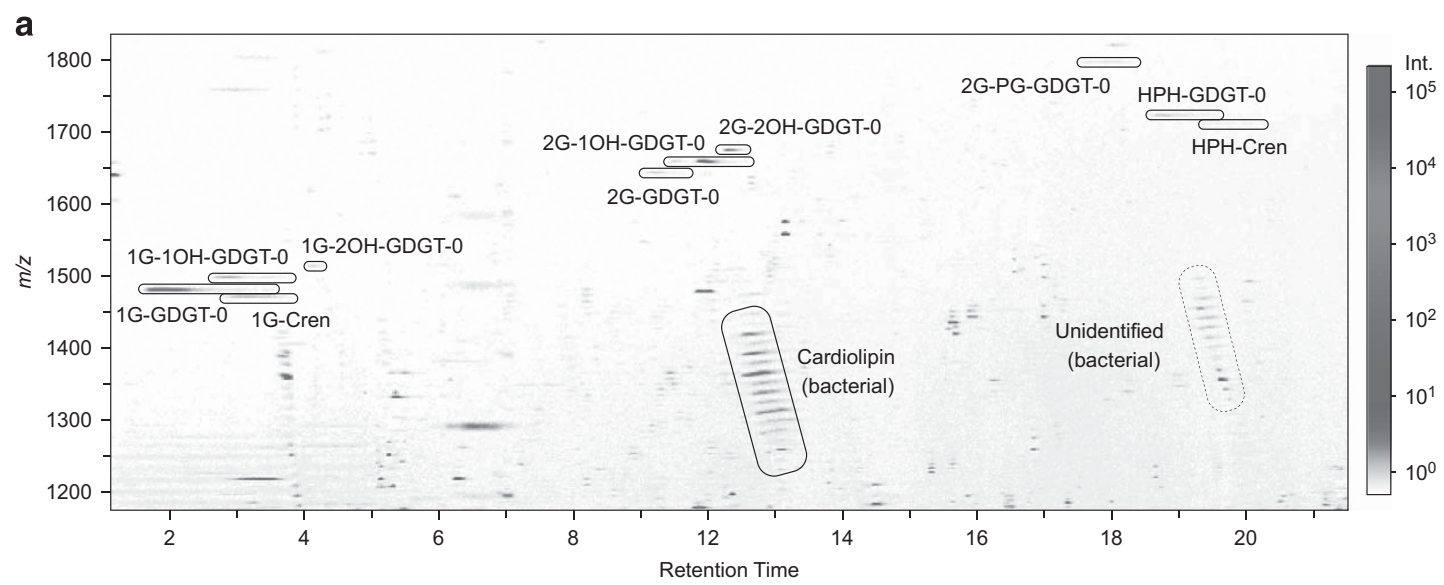

b
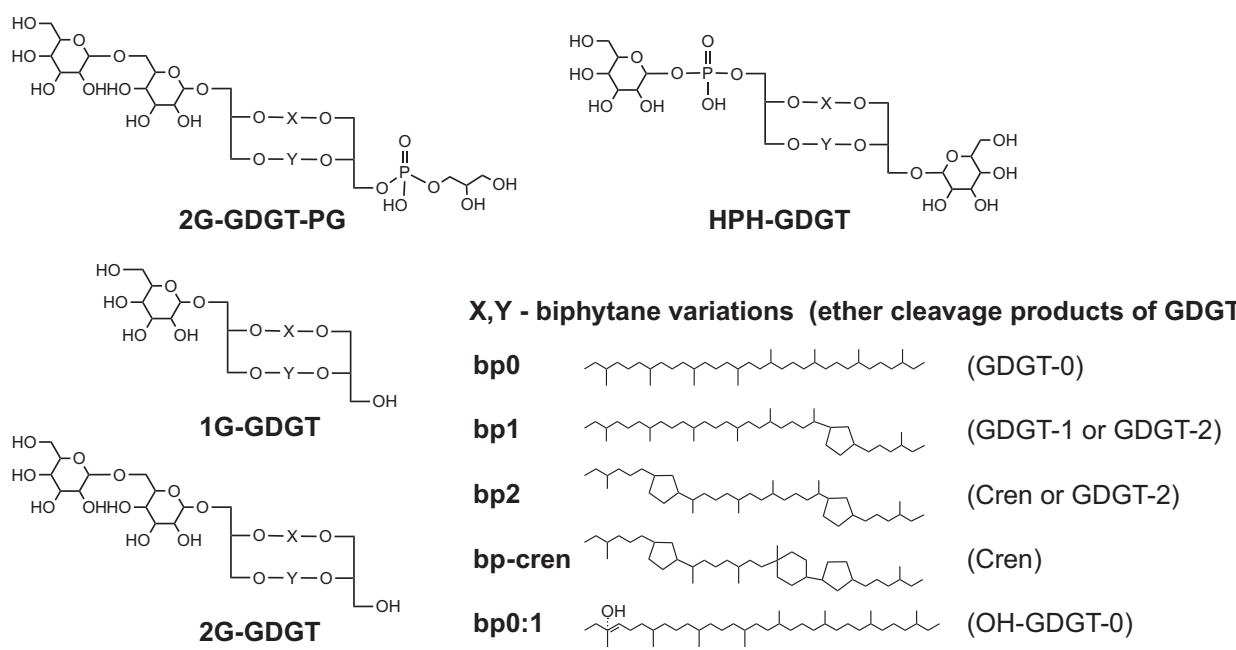

Figure 4 (a) Representative HPLC-MS chromatogram (HILIC-ESI-MS) from site U1357, 7.15 mbsf, showing the presence of major intact polar lipid isoprenoidal glycerol dialkyl glycerol tetraethers (IPL-GDGTs) and bacterial lipids in the mass range $\mathrm{m} / \mathrm{z} 1200-1800$. The HPLC-MS chromatogram is depicted as a density map showing retention time on the $x$ axis, $\mathrm{m} / \mathrm{z}$ on the $y$ axis and the relative peak intensity by grey shading. (b) Structural variety in the head groups and biphytanyl moieties of the detected IPL-GDGTs. Note that during the ether cleavage reaction the hydroxyl group in the biphytane (bp) side chain becomes dehydrated and forms biphytene (bp0:1). Position of the hydroxyl group and double bond were not determined. 1G, monohexose; 2G, dihexose; PG, phosphatidyl glycerol; HPH, hexosephoshohexose; cren, crenarchaeol.

2012). The most abundant phosphatidic GDGTs recovered were with hexose-phosphohexose head groups (HPH, Figures 4 and 5). These lipids likely originated from benthic Thaumarchaeota, the most abundant archaeal organisms according to $16 \mathrm{~S}$ rRNA gene sequences assembled with Emirge (Figure 2). The majority of these sequences were classified as the genus Nitrosopumilus (54\% of the archaeal sequences at $14 \mathrm{~m}$ ). Cultured Nitrosopumilus species produce substantial amounts of HPH-GDGTs with 0-4 cyclopentyl rings and crenarchaeol and have thus been used as environmental biomarkers for Thaumarchaeota (Schouten et al., 2008; Schubotz et al., 2009; Pitcher et al., 2011; Könneke et al., 2012; Elling et al., 2015).

We consider acyclic diglycosyl phosphatidylglycerol-GDGTs (2G-PG-GDGT) as a diagnostic biomarker for the in situ methanogens of this basin. The rationale for this suggestion builds on the following observations: (i) acyclic GDGT is the sole GDGT found in methanogenic archaeal cultures (Koga and Nakano, 2008), (ii) 2G-PG-GDGT has so far only been detected in $\mathrm{CH}_{4}$-rich sediments with comparably depleted $\delta^{13} \mathrm{C}$ values (Schubotz et al., 2011; Yoshinaga et al., 2015), (iii) it is absent from our $\mathrm{CH}_{4}$-free control site (Figure 5) and (iv) 2G-PG-GDGT is not present in known Thaumarchaeota cultures (Elling et al., 2017); thus Thaumarchaeota sources for this lipid can be excluded. So far, only two strains of Methanosaeta have been investigated for their IPL composition: M. concilii contained mainly archaeolbased lipids, while Methanosaeta thermophila contained GDGT-0. Their detected head groups were glycosidic, phosphatidyl ethanolamine and phosphatidyl inositol (Koga and Nakano, 2008). We note that, even though PG was not detected as head group in these two representatives, it cannot be excluded that other species might produce PG in the environment. Absolute concentrations of 2G-PG-GDGTs increase from $\sim 60 \mathrm{ng} \mathrm{g}^{-1}$ at $2 \mathrm{mbsf}$ to $150 \mathrm{ngg}^{-1}$ at 
a

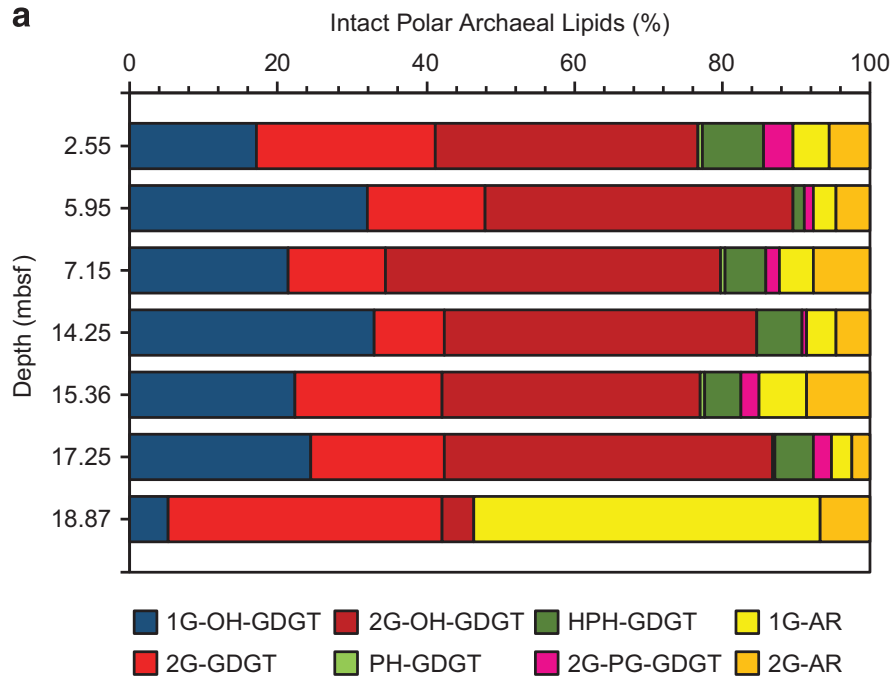

C

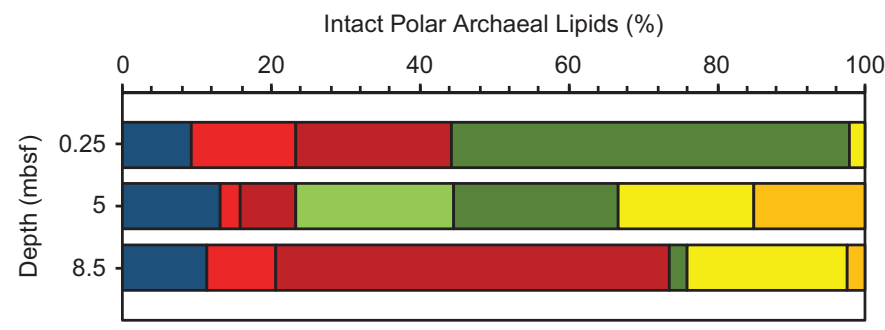

b

$\rightarrow$ Total Archaeal IPLs $\left(\mu \mathrm{g} \mathrm{g} \mathrm{g}^{-1}\right)$

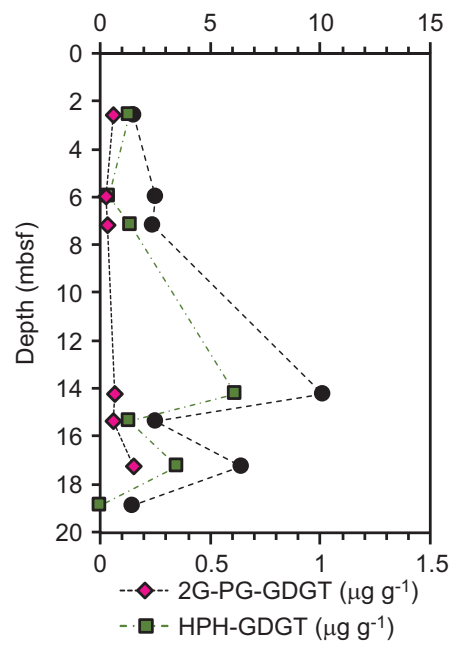

d

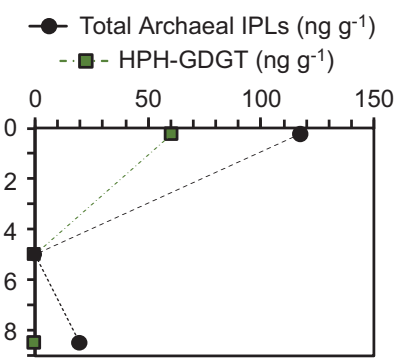

Figure 5 (a) Relative abundances of archaeal intact polar lipid with depth at Hole U1357C. (b) Absolute concentrations of 2G-PG-GDGTs and HPH-GDGTs compared with total intact polar lipids at Hole U1357C. (c) Relative abundances of archaeal intact polar lipid with depth at Hole U1359B. (d) Absolute concentrations of HPH-GDGTs compared with intact polar lipids at Hole U1359B. For abbreviations of intact polar lipid compound classes and source assignments, see Figure 4. Note that 1G-GDGT is excluded in all plots owing to a large assumed fossil component of this lipid, see text.

Table 2 Methane Index (MI) and Branched/Isoprenoid Tetraether (BIT) index at sites U1357 (Adélie Basin site) and U1359 (margin site)

\begin{tabular}{|c|c|c|c|c|c|c|c|c|c|c|}
\hline \multirow[b]{2}{*}{ mbsf } & \multicolumn{7}{|c|}{ Site U1357 (mbsf) } & \multicolumn{3}{|c|}{ Site U1359 (mbsf) } \\
\hline & 2.55 & 5.95 & 7.15 & 14.25 & 15.36 & 17.25 & 18.87 & 0.25 & 5.00 & 9.50 \\
\hline \multicolumn{11}{|l|}{ Index } \\
\hline MI & 0.08 & 0.08 & 0.07 & 0.08 & 0.06 & 0.08 & 0.11 & 0.13 & 0.14 & 0.09 \\
\hline BIT & 0.01 & 0.03 & 0.02 & 0.02 & 0.03 & 0.02 & 0.02 & 0.86 & 0.43 & 0.42 \\
\hline
\end{tabular}

Abbreviation: mbsf, meters below seafloor. MI values $>0.4$ indicate the presence of microbial communities conducting the anaerobic oxidation of methane (Zhang et al., 2011). The BIT index was determined after Hopmans et al. (2004) and the MI after Zhang et al. (2011) using the following Equations: BIT = ([GDGT-I]+[GDGT-II]+[GDGT-III])/([Crenarchaeol]+[GDGT-I]+[GDGT-II]+[GDGT-III]); MI = ([GDGT-1]+[GDGT-2]+[GDGT-3])/

([GDGT-1]+[GDGT-2]+[GDGT-3]+[Crenarchaeol]+[Crenarchaeol Isomer]). BIT values $>0.4$ indicate a high contribution of terrestrial material to the organic material (Hopmans et al., 2004).

17.25 mbsf (Figure 5, Supplementary Table S5). 2GPG-GDGTs were below detection limits at $18 \mathrm{mbsf}$, possibly because sediment quantity was limited at this depth. The relative abundance of 2G-PG-GDGTs compared with total archaeal IPL, and excluding 1GGDGT, varies between $0.6 \%$ and $3.9 \%$ and compares well to the relative abundance of Methanosaeta $16 \mathrm{~S}$ rRNA gene sequences, confirming the relatively low abundances of methanogenic biomass.

$\delta^{13} C$ values of IPL derivatives. We investigated head group-specific $\delta^{13} \mathrm{C}$ of biphytanes to further understand IPL sources (Figure 6). The $\delta^{13} \mathrm{C}$ of biphytanes derived from core-GDGT, (including biphytane $0: 1$, which is the ether cleavage product from core OH-GDGT) range from $-24 \%$ to $-21 \%$ (Supplementary Table S6) and represent end member values presumed to be derived from planktonic archaea (Pearson et al., 2016). The $\delta^{13} \mathrm{C}$ of biphytanes derived from 1G-GDGT mirror core-GDGTs values, confirming that these IPLs are likely planktonic signatures. More depleted $\delta^{13} \mathrm{C}$ values were observed for biphytanes derived from 2G-GDGT and 2G-PGGDGT $(-31 \%$ o to $-23 \%)$, indicating indigenous 

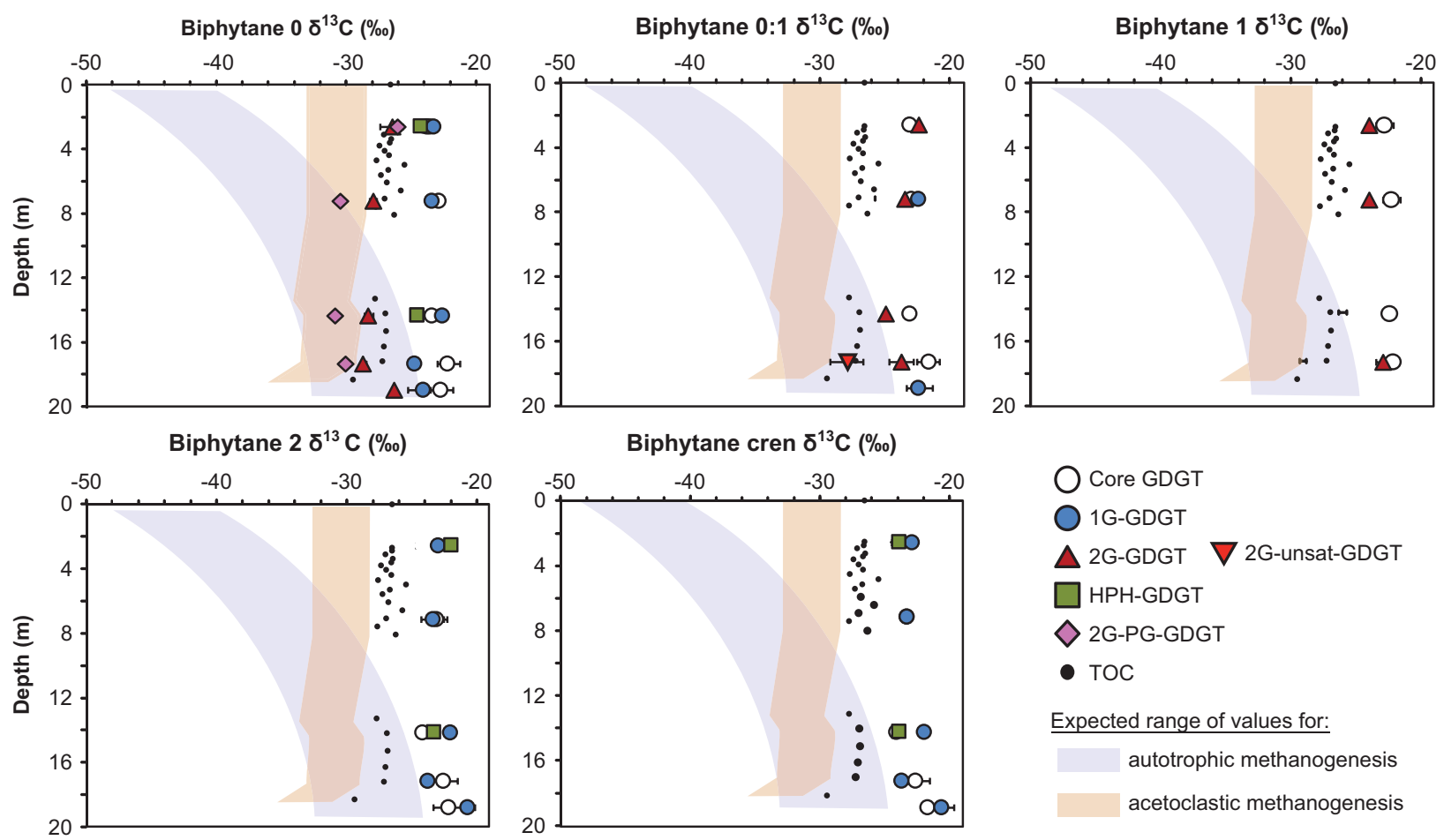

Expected range of values for: autotrophic methanogenesis acetoclastic methanogenesis

Figure 6 Stable carbon isotopic composition $\left(\delta^{13} \mathrm{C}\right)$ of biphytanes derived from IPL-GDGTs with depth. Estimated $\left(\delta^{13} \mathrm{C}\right)$ values were calculated for autotrophic and acetoclastic metabolisms based on observed fractionation patters of Methanosarcina barkeri (Londry et al., 2008). The $\delta^{13} \mathrm{C}$ range for lipids of autotrophic methanogens was estimated using predicted $\delta^{13} \mathrm{C}$ bicarbonate values, which were calculated from measured $\delta^{13} \mathrm{C}$ values of DIC using the observed relation of Mook et al. (1974) and assuming summer bottom water to be $-0.5{ }^{\circ} \mathrm{C}$. The $\delta^{13} \mathrm{C}$ range for lipids of acetoclastic methanogens was estimated using $\delta^{13} \mathrm{C}$ values of TOC.

benthic archaeal communities. 2G-PG-GDGT (bp0) were most ${ }^{13} \mathrm{C}$-depleted $(-31 \%)$, suggesting that compared with the general archaeal community, the source organism used either a lighter carbon source or a metabolism with a larger isotope fractionation during lipid production. These observations support the use of 2G-PG-GDGT as a diagnostic biomarker for in situ methanogens.

Interpretation of carbon cycling. Increasing ammonium and DIC concentrations with depth indicate remineralization of organic matter by heterotrophic archaea and bacteria (Figure 1). The increasing $\delta^{13} \mathrm{C}_{\text {DIC }}$ values with depth are contrary to the expectation for simple OM remineralization (Burdige, 2006) but compare to other $\mathrm{CH}_{4}$-rich sediments (Paull, et al., 2000; Heuer et al., 2009; Torres and Kastner, 2009; Wehrmann, et al., 2011). Increasing $\delta^{13} \mathrm{C}_{\mathrm{DIC}}$ values could result from three processes: (i) the oxidation of ${ }^{13} \mathrm{C}$-depleted $\mathrm{CH}_{4}$ in shallow sediments by anaerobic oxidation of methane (AOM), (ii) selective removal of ${ }^{12} \mathrm{CO}_{2}$ by autotrophic microorganisms, including methanogens, and (iii) acetoclastic methanogenesis, where the disproportionation of acetate results in ${ }^{13} \mathrm{C}-$ depleted $\mathrm{CH}_{4}$ and ${ }^{13} \mathrm{C}$-enriched $\mathrm{CO}_{2}$.

We exclude the possibility of AOM (i) because we did not detect any AOM genomic biomarkers, hydroxyarchaeols or ${ }^{13} \mathrm{C}$-depleted biphytanes derived from 2G-GDGT, as would be expected if
ANME-2 or ANME-1 archaea were present (Blumenberg et al., 2004; Schubotz et al., 2011; Yoshinaga et al., 2015). Additionally, we used the MI of core GDGTs to assess the potential presence of $\mathrm{CH}_{4}$-oxidizing archaea by comparing relative abundances of GDGTs with 1,2 and 3 pentacyclic rings relative to crenarchaeol (Zhang et al., 2011). MI values were $<0.17$ at all depths (Table 2), indicating that $\mathrm{AOM}$ is not a dominant process in sediments up to $20 \mathrm{~m}$ depth.

We can exclude bacterial autotrophy (ii) based on metagenomic and lipid analyses. Most bacterial 16S rRNA gene sequences assembled with Emirge were classified as heterotrophs based on the metabolisms of closely related cultured organisms (Carr et al., 2015). Heterotrophic bacteria are consistent with bacterial ${ }^{13} \mathrm{C}_{\text {FAmES }}$ values, which do not track changing $\delta^{13} \mathrm{C}_{\mathrm{DIC}}$ values (Supplementary Figure S4, Supplementary Table S8) but fall within the range of ${ }^{13} \mathrm{C}$ values expected for bacterial anaerobic heterotrophs, which can be depleted by $-12 \%$ relative to $\delta^{13} \mathrm{C}_{\mathrm{TOC}}$ values (Teece et al., 1999). The presence of autotrophic archaea is less clear. The genus Nitrosopumilus represents the most abundant archaeal lineage. Cultured Nitrosopumilus species can fix carbon using the 3-hydroxypropionate/4hydroxybutyrate (HP/HB) cycle and assimilate organic carbon (Walker et al., 2010; Könneke et al., 2012; Qin et al., 2014; Hurley et al., 2016). The 
co-assembled metagenome contained 32 gene sequences for 3-hydroxypropionyl-coenzyme A dehydratase, a required HP/HB cycle enzyme (Supplementary Table S9). All sequences were classified as Thaumarchaeota using BLASTp, suggesting that Nitrosopumilus autotrophy is possible. Considering Nitrosopumilus HPH-GDGT and PH-GDGT biomarkers, previous studies have demonstrated that isotopic fractionation during lipid production by autotrophic Nitrosopumilus species ( $\left.\varepsilon_{\text {DIC-byphytanes }}\right)$ is $-20 \%$ (Könneke et al., 2012). Here $\delta^{13} \mathrm{C}$ values of HPH-GDGTs are approximately $-24 \%$ resulting in $\varepsilon_{\text {DIC-biphytanes }}$ values of approximately $-10 \%$ at $2.5 \mathrm{mbsf}$ and $-20 \%$ at $14 \mathrm{mbsf}$ (Supplementary Tables S6 and S8). This suggests that Nitrosopumilus $\mathrm{CO}_{2}$ fixation is possible at $14 \mathrm{mbsf}$ but does not fully explain $\delta^{13} \mathrm{C}$ values at $2.5 \mathrm{mbsf}$. Alternatively, given that HPH-GDGT $\delta^{13} \mathrm{C}$ values are constant with depth, maybe Nitrosopumilus are heterotrophic or mixotrophic. If mixotrophic, Thaumarchaota may be contributing to DIC enrichment with depth but using an isotopically heavy fraction of the TOC pool as substrates for lipid production or maybe recycling the relic and ${ }^{13} \mathrm{C}$-enriched isoprenoids that are prevalent in these sediments (Takano et al., 2010).

Based on $\delta^{13} \mathrm{C}_{\text {Lipids }}$ calculations of the methanogenic biomarker 2G-PG-GDGT(0) and the observations made by Londry et al., 2008, we conclude that acetoclastic methanogenesis (iii) is a likely control on ${ }^{13} \mathrm{C}$ enrichment of DIC with depth and that acetoclastic methanogenesis is responsible for the majority of the produced $\mathrm{CH}_{4}$. Assuming that pure culture studies with Methanosarcina by Londry et al. (2008) represents environmental metabolisms, we calculated theoretical fractionation effects for both autotrophic $\mathrm{CO}_{2}$ reduction and acetoclastic methanogenesis (Figure 6). As $\delta^{13} \mathrm{C}_{\text {DIC }}$ values become continuously heavier with depth, we would expect the $\delta^{13} \mathrm{C}_{\text {Lipids }}$ of $\mathrm{CO}_{2}$-reducing archaea to follow this trend; however, this is not the case for the biphytane lipids derived from 2-PG-GDGT (Figure 6). Instead, these lipids fall within the expected $\delta^{13} \mathrm{C}$ range of acetoclastic methanogenesis, being between $2 \%$ and $7 \%$ lighter than $\delta^{13} \mathrm{C}_{\mathrm{TOC}}$. This is in agreement with previous environmental investigations where it was consistently observed that the carboxyl carbon of acetate is $4-20 \%$ heavier than the methyl carbon (Blair and Carter, 1992; Heuer et al., 2009). Consequently, the disproportionation of acetate in sedimentary environments often contributes to a ${ }^{13} \mathrm{C}$ enriched DIC pool (Heuer, et al., 2010), despite increasing concentrations of DIC due to overall organic matter remineralization.

\section{Conclusion}

Subsurface methanogens are difficult to detect and metabolically characterize in sediment environments. We employed genomic and lipid analyses to identify Methanosaeta as the sole methanogen at
14 mbsf. The resulting GFM represents the first partial genome for deep-subsurface Methanosaeta and verifies that deep-subsurface Methanosaeta contain gene-encoded proteins for acetoclastic and $\mathrm{CO}_{2}$-reducing methanogenesis, similar to surface isolates. The lack of an energy-conserving hydrogenase and known electron transferring syntrophs suggest that these Methanosaeta use acetate and benefit from the fermentation products of heterotrophs. IPL analysis identified 2G-PG-GDGT as a diagnostic marker for methanogens in these sediments. The $\delta^{13} \mathrm{C}$ of this lipid was around $-30 \%$, consistent with acetoclastic methanogenesis. Relative abundances of 2G-PG-GDGT represent $0.6-3.9 \%$ of archaeal IPLs and support the metagenomic results, which suggest that Methanosaeta represent $5 \%$ and $0.2 \%$ of the sequenced archaeal and total community at $14 \mathrm{mbsf}$, respectively. Although this methanogenic population is relatively small, the phosphatidic biomarkers suggest that these organisms were active when sampled, and an important $\mathrm{CH}_{4}$ source in the Adélie basin, and may fill a similar ecological role in other anoxic basins.

\section{Conflict of Interest}

The authors declare no conflict of interest.

\section{Acknowledgements}

We thank the shipboard party of IODP Expedition 318 for supporting this work, especially co-chiefs Escutia and Brinkhuis, Staff Scientist Klaus and geochemistry team: James Bendle, Tina van de Flierdt, and Francisco JimenezEspejo. We thank Charles Pepe-Ranney and Benjamin Tully for bioinformatics assistance, David Mucciarone for isotope geochemistry assistance, Kai-Uwe Hinrichs and John Spear for the use of their facilities, Julius Lipp for provision of IPL standards and Beth Orcutt for manuscript comments. The Deep Carbon Observatory's Census of Deep Life project funded by the Alfred P Sloan Foundation provided sequencing services. Carr was funded by the US National Science Foundation (NSF OCE-0939564) and the Center for Dark Energy Biosphere Investigations (funded by NSF OCE-1521614, publication no. 390). FS and RES acknowledge funding from NASA Astrobiology grant (NNA13AA90A) and the Central Research Development Fund, University of Bremen. Any use of trade, firm or product names is for descriptive purposes only and does not imply endorsement by the US Government.

\section{References}

Alneberg J, Bjarnason BS, de Bruijn I, Schirmer M, Quick J, Ijaz UZ et al. (2014). Binning metagenomic contigs by coverage and composition. Nat Methods 11: 1144-1146. Aziz RK, Bartels D, Best AA, DeJongh M, Disz T, Edwards R et al., ( (2008). The RAST server: Rapid Annotations using Subsystems Technology. BMC Genomics 9: 1-15. 
Bankevich A, Nurk S, Antipov D, Gurevich AA, Dvorkin M, Kulikov AS et al. (2012). SPAdes: a new genome assembly algorithm and its applications to single-cell sequencing. J Comput Biol 19: 455-477.

Barber RD, Zhang L, Harnack M, Olson MV, Kaul R, Ingram-Smith C et al. (2011). Complete genome sequence of Methanosaeta concilii, a specialist in aceticlastic methanogenesis. J Bacteriol 193: 3668-3669.

Becker KW, Lipp JS, Zhu C, Liu X-L, Hinrichs K-U. (2013). An improved method for analysis of archaeal and bacterial ether core lipids. Org Geochem 61: 34-44.

Biddle JF, Lipp JS, Lever MA, Lloyd KG, Sørensen KB, Anderson $\mathrm{R}$ et al. (2006). Heterotrophic Archaea dominate sedimentary subsurface ecosystems off Peru. PNAS 103: 3846-3851.

Biddle JF, Fitz-Gibbon S, Schuster SC, Brenchley JE, House CH. (2008). Metagenomic signatures of the Peru Margin subseafloor biosphere show a genetically distinct environment. PNAS 105: 10583-10588.

Blair NE, Carter WD. (1992). The carbon isotope biogeochemistry of acetate from a methanogenic marine sediment. Geochim Cosmochim Acta 56: 1247-1258.

Blumenberg M, Seifert R, Reitner J, Pape T, Michaelis W. (2004). Membrane lipid patterns typify distinct anaerobic methanotrophic consortia. PNAS 101: 11111-11116.

Bray NL, Pimentel H, Melsted P, Pachter L. (2016). Nearoptimal probabilistic RNA-seq quantification. Nat Biotech 34: 525-527.

Burdige DJ. (2006). Geochemistry of Marine Sediments. Princeton University Press: Princeton, NJ, USA.

Bushnell B. (2015). BBMap. Available at: http://source forge.net/projects/bbmap/.

Carr SA, Orcutt BN, Mandernack KW, Spear JR. (2015). Abundant Atribacteria in deep marine sediment from the Adélie Basin, Antarctica. Front Microbiol 6: 1-12.

Carr SA, Mills CT, Mandernack KW. (2016). The use of amino acid indices for assessing organic matter quality and microbial abundance in deep-sea Antarctic sediments of IODP Expedition 318. Mar Chem 186: 72-82.

Carr SA, Vogel SW, Dunbar RB, Brandes J, Spear JR, Levy R et al. (2013). Bacterial abundance and composition in marine sediments beneath the Ross Ice Shelf, Antarctica. Geobiology 11: 377-395.

Colwell FS, Boyd S, Delwiche ME, Reed DW, Phelps TJ, Newby DT. (2008). Estimates of biogenic methane production rates in deep marine sediments at Hydrate Ridge, Cascadia Margin. Appl Environ Microb 74: 3444-3452.

Dodsworth JA, Blainey PC, Murugapiran SK, Swingley WD, Ross CA, Tringe SG et al. (2013). Single-cell and metagenomic analyses indicate a fermentative and saccharolytic lifestyle for members of the OP9 lineage. Nat Commun 4: 1810-1854.

Elling FJ, Könneke M, Mußmann M, Greve A, Hinrichs K-U. (2015). Influence of temperature, $\mathrm{pH}$, and salinity on membrane lipid composition and TEX86 of marine planktonic thaumarchaeal isolates. Geochim Cosmochim Acta 171: 238-255.

Elling FJ, Könneke M, Nicol GW, Stieglmeier M, Bayer B, Spieck E et al. (2017). Chemotaxonomic characterisation of the thaumarchaeal lipidome. Environ Microb 171: 238-255.

Eren AM, Esen ÖC, Quince C, Vineis JH, Morrison HG, Sogin ML et al. (2015). Anvi'o: an advanced analysis and visualization platform for 'omics data'. PeerJ 3: e1319.
Expedition 318 Scientists. (2011a). Methods. In: Escutia C, Brinkhuis H, Klaus A, the Expedition 318 Scientists (eds). Proc. IODP, 318. Integrated Ocean Drilling Program Management International, Inc: Tokyo, Japan.

Expedition 318 Scientists. (2011b). Site U1357. In: Escutia C, Brinkhuis H, Klaus A, the Expedition 318 Scientists (eds). Proc. IODP, 318. Integrated Ocean Drilling Program Management International, Inc.: Tokyo, Japan.

Ferdelman TG, Lee C, Pantoja S, Harder J, Bebout BM, Fossing H. (1997). Sulfate reduction and methanogenesis in a Thioploca-dominated sediment off the coast of Chile. Geochim Cosmochim Acta 61: 3065-3079.

Ferry JG, Kastead KA. (2007). Methanogenesis. In: Cavicchioli R (ed). Archaea: Molecular and Cellular Biology. ASM Press: Washington, DC, USA, pp 288-314.

Ferry JG, Lesser DJ. (2008). Methanogenesis in marine sediments. Ann NY Acad Sci 1125: 147-157.

Fitzsimons MF, Jemmett AW, Wolff GA. (1997). A preliminary study of the geochemistry of methylamines in a salt marsh. Org Geochem 27: 15-24.

Gies EA, Konwar KM, Beatty JT, Hallam SJ. (2014). Illuminating microbial dark matter in Meromictic Sakinaw Lake. Appl Environ Microb 80: 6807-6818.

Gruber N, Keeling CD, Bacastow RB, Guenther PR, Lueker TJ, Wahlen $\mathrm{M}$ et al. (1999). Spatiotemporal patterns of carbon-13 in the global surface oceans and the oceanic suess effect. Global Biogeochem Cy 13: 307-335.

Heuer VB, Krüger M, Evert M, Hinrichs K-U. (2010). Experimental studies on the stable carbon isotope biogeochemistry of acetate in lake sediments. Org Geochem 41: 22-30.

Heuer VB, Pohlman JW, Torres ME, Elvert M. (2009). The stable carbon isotope biogeochemistry of acetate and other dissolved carbon species in deep subseafloor sediments at the northern Cascadia Margin. Geochim Cosmochim Acta 73: 3323-3336.

Hopmans EC, Weijers JWH, Schefuß E, Herfort L, Sinninghe Damsté JS, Schouten S. (2004). A novel proxy for terrestrial organic matter in sediments based on branched and isoprenoid tetraether lipids. Earth Planet Sci Lett 224: 107-116.

Huang Y, Gilna P, Li W. (2009). Identification of ribosomal RNA genes in metagenomic fragments. Bioinformatics 25: $1338-1340$.

Huguet C, Hopmans EC, Febo-Ayala W, Thompson DH, Sinninghe Damsté JS, Schouten S. (2006), An improved method to determine the absolute abundance of glycerol dibiphytanyl glycerol tetraether lipids. Org Geochem 37: 1036-1041.

Hurley SJ, Elling FJ, Könneke M, Buchwald C, Wankel SD, Santoro AE et al. (2016). Influence of ammonia oxidation rate on thaumarchaeal lipid composition and the TEX86 temperature proxy. PNAS 113: 7762-7767.

Inagaki F, Nunoura T, Nakagawa S, Teske A, Lever M, Lauer A et al. (2006). Biogeographical distribution and diversity of microbes in methane hydrate-bearing deep marine sediments on the Pacific Ocean Margin. PNAS 103: 2815-2820.

Jahn U, Summons R, Sturt H, Grosjean E, Huber H. (2004). Composition of the lipids of Nanoarchaeum equitans and their origin from its host Ignicoccus sp. strain KIN4/I. Arch Microbiol 182: 404-413.

Katayama T, Yoshioka H, Takahashi HA, Amo M, Fujii T, Sakata S. (2016). Changes in microbial communities 
associated with gas hydrates in subseafloor sediments from the Nankai Trough. FEMS Microbiol Ecol 92: $1-10$.

Koga Y, Nakano M. (2008). A dendrogram of archaea based on lipid component parts composition and its relationship to rRNA phylogeny. Syst Appl Microbiol 31: 169-182.

Könneke M, Lipp JS, Hinrichs K-U. (2012). Carbon isotope fractionation by the marine ammonia-oxidizing archaeon Nitrosopumilus maritimus. Org Geochem 48: 21-24.

Lang K, Klingl A, Poehlein A, Daniel R, Brune A. (2015). New mode of energy metabolism in the seventh order of methanogens as revealed by comparative genome analysis of 'Candidatus Methanoplasma termitum'. Appl Environ Microb 81: 1338-1352.

Lengger SK, Hopmans EC, Reichart G-J, Nierop KGJ, Sinninghe Damsté JS, Schouten S. (2012). Intact polar and core glycerol dibiphytanyl glycerol tetraether lipids in the Arabian Sea oxygen minimum zone. Part II: Selective preservation and degradation in sediments and consequences for the TEX86. Geochim Cosmochim Acta 98: 244-258.

Leventer A, Domack E, Dunbar R, Pike J, Stickley C, Maddison E et al., (2006). Marine sediment record from the East Antarctic margin reveals dynamics of ice sheet recession. GSA Today 16: 4-10.

Li D, Liu C-M, Luo R, Sadakane K, Lam T-W. (2015). MEGAHIT: an ultra-fast single-node solution for large and complex metagenomics assembly via succinct de Bruijn graph. Bioinformatics 31: 1674-1676.

Liang B, Wang LY, Mbadinga SM, Liu JF, Yang SZ, Gu JD et al. (2015). Anaerolineaceae and Methanosaeta turned to be the dominant microorganisms in alkanes-dependent methanogenic culture after longterm of incubation. AMB Express 5: 1-13

Lipp JS, Hinrichs K-U. (2009). Structural diversity and fate of intact polar lipids in marine sediments. Geochim Cosmochim Acta 73: 6816-6833.

Lipp JS, Morono Y, Inagaki F, Hinrichs K-U. (2008). Significant contribution of Archaea to extant biomass in marine subsurface sediments. Nature 454: 991-994.

Liu X-L, Lipp JS, Schröder JM, Summons RE, Hinrichs K-U. (2012). Isoprenoid glycerol dialkanol diethers: a series of novel archaeal lipids in marine sediments. Org Geochem 43: 50-55.

Londry KL, Dawson KG, Grover HD, Summons RE, Bradley AS. (2008). Stable carbon isotope fractionation between substrates and products of Methanosarcina barkeri. Org Geochem 39: 608-621.

Lovell CR, Przybyla A, Ljungdahl LG. (1990). Primary structure of the thermostable formyltetrahydrofolate synthetase from Clostridium thermoaceticum. Biochemistry 29: 5687-5694.

Ma K, Liu X, Dong X. (2006). Methanosaeta harundinacea sp. nov., a novel acetate-scavenging methanogen isolated from a UASB reactor. Int J Syst Evol Microbiol 56: $127-131$.

Markowitz VM, Chen I-MA, Palaniapan K, Chu k, Szeto E, Pillay $\mathrm{M}$ et al. (2014). IMG 4 version of the integrated microbial genomes comparative analysis system. Nucleci Acids Res 43: D560-D567.

Miller CS, Baker BJ, Thomas BC, Singer SW, Banfield JF. (2011). EMIRGE: reconstruction of full-length ribosomal genes from microbial community short read sequencing data. Genome Biol 12: 1-14.
Mills CT, Slater GF, Dias RF, Carr SA, Reddy CM, Schmidt R et al. (2013). The relative contribution of methanotrophs to microbial communities and carbon cycling in soil overlying a coal-bed methane seep. FEMS Microbiol Ecol 84: 474-494.

Mook WG, Bommerson JC, Staverman WH. (1974). Carbon isotope fractionation between dissolved bicarbonate and gaseous carbon dioxide. Earth Planet Sci Lett 22: 169-176.

Mori K, Iino T, Suzuki KI, Yamaguchi K, Kamagata Y. (2012). Aceticlastic and NaCl-requiring methanogen 'Methanosaeta pelagica' sp. Nov., isolated from marine tidal flat sediment. Appl Environ Microb 78: 34163423.

Nobu MK, Narihiro T, Rinke C, Kamagata Y, Tringe SG, Woyke T et al. (2015). Microbial dark matter ecogenomics reveals complex synergistic networks in a methanogenic bioreactor. ISME J 9: 1710-1722.

Pancost RD, Sinninghe Damsté JS. (2003). Carbon isotopic compositions of prokaryotic lipids as tracers of carbon cycling in diverse settings. Chem Geol 195: 29-58.

Parkes RJ, Webster G, Cragg BA, Weightman AJ, Newberry CJ, Ferdelman TG et al. (2005). Deep sub-seafloor prokaryotes stimulated at interfaces over geological time. Nature 436: 390-394.

Parks DH, Imelfort M, Skennerton CT, Hugenholtz P, Tyson GW. (2015). CheckM: assessing the quality of microbial genomes recovered from isolates, single cells, and metagenomes. Genome Res 25: 1043-1055.

Patel GB. (1984). Characterization and nutritional properties of Methanothrix concilii sp. nov., a mesophilic, aceticlastic methanogen. Can J Microbiol 30: 1383-1396.

Paull CK, Lorenson TD, Borowski WS, Ussler W, Olsen K, Rodriguez NM. (2000). Isotopic composition of $\mathrm{CH}_{4}$ and $\mathrm{CO}_{2}$ species, and sedimentary organic matter within samples from the Blake Ridge: gas source implications. In: Paull CK, Matsumoto R, Wallace PJ, Dillon WP(eds). Proceedings of the Ocean Drilling Program, Scientific Results. Ocean Drilling Program: College Station, TX, USA, vol. 164, pp 67-78.

Pearson A, Hurley SJ, Walter SRS, Kusch S, Lichtin S, Zhang YG. (2016). Stable carbon isotope ratios of intact GDGTs indicate heterogeneous sources to marine sediments. Geochim Cosmochim Acta 181: 18-35.

Pitcher A, Hopmans EC, Mosier AC, Park S-J, Rhee S-K, Francis CA et al., (2011). Core and intact polar glycerol dibiphytanyl glycerol tetraether lipids of ammoniaoxidizing archaea enriched from marine and estuarine sediments. Appl Environ Microb 77: 3468-3477.

Quast C, Pruesse E, Yilmaz P, Gerken J, Schweer T, Yarza P et al. (2013). The SILVA ribosomal RNA gene database project: improved data processing and webbased tools. Nucleic Acids Res 41: D590-D596.

Qin W, Amin SA, Martens-habbena W, Walker CB, Urakawa H, Devol AH. (2014). Marine ammoniaoxidizing archaeal isolates display obligate mixotrophy and wide ecotypic variation. PNAS 111: 12504-12509.

Reeburgh WS. (2007), Oceanic methane biogeochemistry. Chem Rev 107: 486-513.

Rodriguez-R LM, Konstantinidis KT. (2014). Nonpareil: a redundancy-based approach to assess the level of coverage in metagenomic datasets. Bioinformatics $\mathbf{3 0}$ 629-635.

Rotaru AE, Shrestha D, Embree M, Zengler K, Wardman C. (2014). A new model for electron flow during anaerobic digestion: direct interspecies electron transfer to 
Methanosaeta for the reduction of carbon dioxide to methane. Energy Environ Sci 7: 408-415.

Schouten S, Hopmans EC, Baas M, Boumann H, Standfest S, Könneke $\mathrm{M}$ et al. (2008). Intact membrane lipids of 'Candidatus Nitrosopumilus maritimus,' a cultivated representative of the cosmopolitan mesophilic group I Crenarchaeota. Appl Environ Microb 74: 2433-2440.

Schouten S, Middelburg J, Hopmans EC, Sinninghe Damsté JS. (2010). Fossilization and degradation of intact polar lipids in deep subsurface sediments: a theoretical approach. Geochim Cosmochim Acta 74: 3806-3814.

Schubotz F, Wakeham SG, Lipp JS, Fredricks HF, Hinrichs K. (2009). Detection of microbial biomass by intact polar membrane lipid analysis in the water column and surface sediments of the Black Sea. Environ Microbiol 11: $2720-2734$.

Schubotz F, Lipp JS, Elvert M, Hinrichs K-U. (2011). Stable carbon isotopic compositions of intact polar lipids reveal complex carbon flow patterns among hydrocarbon degrading microbial communities at the Chapopote asphalt volcano. Geochim Cosmochim Acta 75: 4399-4415.

Schubotz F, Meyer-Dombard DR, Bradley AS, Fredricks HF, Hinrichs K-U, Shock EL et al. (2013). Spatial and temporal variability of biomarkers and microbial diversity reveal metabolic and community flexibility in Streamer Biofilm Communities in the Lower Geyser Basin, Yellowstone National Park. Geobiology 11: 549-569.

Smith KS, Ingram-smith C. (2007). Methanosaeta, the forgotten methanogen? Trends Microbiol 15: 150-155.

Sowers KR, Baron SF, Ferry JG. (1984). Methanosarcina acetivorans sp. nov., an acetotrophic methaneproducing bacterium isolated from marine sediments. Appl Environ Microb 47: 971-978.

Sowers KR, Ferry JG. (2003). Methanogenesis in the Marine Environment. Encyclopedia of Environmental Microbiology. John Wiley \& Sons, Inc.: New York, NY, USA.

Takano Y, Chikaraishi Y, Ogawa NO, Nomaki H, Morono Y, Inagaki $\mathrm{F}$ et al., ( (2010). Sedimentary membrane lipids recycled by deep-sea benthic archaea. Nat Geosci 3: 1-4.

Teece MA, Fogel ML, Dollhopf ME, Nealson KH. (1999). Isotopic fractionation associated with biosynthesis of fatty acids by a marine bacterium under oxic and anoxic conditions. Org Geochem 30: 1571-1579.

Torres ME, Kastner M. (2009). Data report: clues about carbon cycling in methane-bearing sediments using stable isotopes of the dissolved inorganic carbon, IODP Expedition 311. In: Riedel M, Collett TS, Malone MJ, the Expedition 311 Scientists (eds). Proc. IODP 311. Integrated Ocean Drilling Program Management International, Inc.: Washington, DC, USA.

Valentine DL. (2002). Biogeochemistry and microbial ecology of methane oxidation in anoxic environments: a review. Van Leeuw J Microb 81: 271-282.

Valentine DL. (2011). Emerging topics in marine methane biogeochemistry. Annu Rev Mar Sci 3: 147-171.
Walker CB, de la Torre JR, Klotz MG, Urakawa H, Pinel N, Arp DJ et al., (2010). Nitrosopumilus maritimus genome reveals unique mechanisms for nitrification and autotrophy in globally distributed marine crenarchaea. PNAS 107: 8818-8823.

Wang Y, Coleman-Derr D, Chen G, Gu YQ. (2015). OrthoVenn: a web server for genome wide comparison and annotation of orthologous clusters across multiple species. Nucleic Acids Res 43: W78-W84.

Wehrmann LM, Risgarrd-Petersen N, Schrum HN, Walsh EA, Huh Y, Ikehara M et al. (2011). Coupled organic and inorganic carbon cycling in the deep subseafloor sediment of the northeastern Bering Sea Slope (IODP Exp. 323). Chem Geol 284: 251-261.

Whiticar M, Faber E, Schoel ML. (1986). Biogenic methane formation in marine and freshwater environments: $\mathrm{CO}_{2}$ reduction vs. acetate fermentation-isotope evidence. Geochim Cosmochim Acta 50: 693-709.

Wörmer L, Lipp JS, Schröder JM, Hinrichs K-U. (2013). Application of two new LC-ESI-MS methods for improved detection of intact polar lipids (IPLs) in environmental samples. Org Geochem 59: 10-21.

Xie S, Lipp JS, Wegener G, Ferdelman TG, Hinrichs K-U. (2013). Turnover of microbial lipids in the deep biosphere and growth of benthic archaeal populations. PNAS 110: 6010-6014.

Xie S, Pancost RD, Chen L, Evershed RP, Yang H, Zhang K et al. (2012). Microbial lipid records of highly alkaline deposits and enhanced aridity associated with significant uplift of the Tibetan Plateau in the Late Miocene. Geology 40: 291-294.

Yoshinaga MY, Kellermann MY, Rossel PE, Schubotz F, Lipp JS, Hinrichs K-U. (2011). Systematic fragmentation patterns of archaeal intact polar lipids by highperformance liquid chromatography/electrospray ionization ion-trap mass spectrometry. Rapid Commun Mass Sp 25: 3563-3574.

Yoshinaga MY, Lazar CS, Elvert M, Lin Y, Zhu C, Heuer VB et al. (2015). Possible roles of uncultured archaea in carbon cycling in methane-seep sediments. Geochim Cosmochim Acta 164: 35-52.

Zhang YG, Zhang CL, Liu X-L, Li L, Hinrichs K-U, Noakes JE. (2011). Methane Index: a tetraether archaeal lipid biomarker indicator for detecting the instability of marine gas hydrates. Earth Planet Sci Lett 307: 525-534.

Zhou J, Bruns MA, Tiedje JM. (1996). DNA recovery from soils of diverse composition. Appl Environ Microb 62: 316-322.

Zhu C, Lipp JS, Wörmer L, Becker KW, Schröder J, Hinrichs K-U. (2013). Comprehensive glycerol ether lipid fingerprints through a novel reversed phase liquid chromatography-mass spectrometry protocol. Org Geochem 65: 53-62.

Zink K-G, Wilkes H, Disko U, Elvert M, Horsfield B. (2003). Intact phospholipids-microbial 'life markers' in marine deep subsurface sediments. Org Geochem 34: 755769 .

Supplementary Information accompanies this paper on The ISME Journal website (http://www.nature.com/ismej) 